\title{
Epibiota communities of the introduced and indigenous macroalgal relatives Sargassum muticum and Halidrys siliquosa in Limfjorden (Denmark)
}

Received: 22 August 2003 / Revised: 12 April 2004 / Accepted: 14 April 2004 / Published online: 9 June 2004 (C) Springer-Verlag and AWI 2004

\begin{abstract}
Sargassum muticum (Phaeophyceae, Fucales) has recently been introduced to Limfjorden (Denmark) where its closest relative is the indigenous Halidrys siliquosa. Previous studies have demonstrated large quantitative (canopy biomass) and qualitative (canopy persistence) differences in the habitat available to epibiota within the canopies of these two macroalgae. We therefore hypothesised that these algae would support different epibiota communities and tested this by sampling the epibiota of $S$. muticum and $H$. siliquosa on seven occasions throughout 1997 by enclosing entire thalli in mesh bags. We found 53 epibiota taxa and, with only one exception, they were all recorded on both host species. Species richness and abundance of epibiota exhibited clear seasonal variation on both host species, although epibiota biomass was seasonally constant on $H$. siliquosa but not on $S$. muticum. These patterns were consistent with the different life histories of the host species. There was a weakly negative correlation between thallus size
\end{abstract}

Communicated by H.-D. Franke

T. Wernberg $(-) \cdot$ M. S. Thomsen · P. A. Staehr · M. F. Pedersen Department of Life Sciences and Chemistry 17.2,

Roskilde University,

P.O. Box 260, 4000 Roskilde, Denmark

e-mail: wernberg@graduate.uwa.edu.au

Tel.: +61-8-83036224

Fax: $+61-8-83034364$

Present address:

T. Wernberg, Southern Seas Ecology Laboratories, DP 418, School of Earth \& Environmental Sciences,

University of Adelaide,

5005 Adelaide, SA, Australia

Present address:

M. S. Thomsen, Department of Environmental Science,

University of Virginia,

Clark Hall, Charlottesville, VA 22903, USA

Present address:

P. A. Staehr, Freshwater Biological Laboratory,

University of Copenhagen,

Helsingørgade 51, 3400 Hillerød, Denmark and epibiota biomass for both host species. When taking species-specific seasonal variation in thallus size into consideration, $S$. muticum and $H$. siliquosa were found to support significantly different epibiota biomasses. Multivariate analyses showed that epibiota community structure was different, although highly overlapping, between the two species, whereas there was an almost parallel temporal development in epibiota community structure. We conclude that it is unlikely that the introduction of $S$. muticum to Limfjorden has caused major changes in local epibiota community structure. However, the standing stock of epibiota is likely to have increased.

Keywords Sargassum muticum - Halidrys siliquosa · Epibiota $\cdot$ Canopy habitat $\cdot$ Community structure

\section{Introduction}

The introduction and subsequent expansion of Sargassum muticum (Yendo) Fensholt as a permanent member of the European algal flora has caused general concern about the effects on indigenous biota (Critchley et al. 1987; Rueness 1989; Thelin 1989; Den Hartog 1997; Karlsson and Loo 1999). Several studies have indicated negative impacts by S. muticum on indigenous algal assemblages (Fletcher and Fletcher 1975; Ambrose and Nelson 1982; Viejo 1997; Cosson 1999; Staehr et al. 2000) but only a limited number of studies have addressed the possible consequences for macroalgal epibiota. Those that have, have suggested few adverse effects, apparently due to a low degree of habitat specificity among the epibiota (Withers et al. 1975; Jephson and Gray 1977; Viejo 1999). Nevertheless, following the introduction of S. muticum to Limfjorden, a shallow Danish sound, biologists noted conspicuously more epibiota associated with $S$. muticum relative to other algae (M. Lauersen, County of Ringkøbing, personal communication).

S. muticum was first recorded in Limfjorden in 1984 (Christensen 1984). Over a period of less than 15 years the population grew from a few isolated individuals to 
become the dominant component of the macroalgal flora (Staehr et al. 2000). Such invasive behaviour is the normal pattern where $S$. muticum has been introduced (Knoepffler-Peguy et al. 1985; Núnez-López and Casas Valdez 1998; Cosson 1999; Fernandez 1999; Karlsson and Loo 1999).

Halidrys siliquosa (L.) Lyngb. is a close relative of $S$. muticum (Jensen 1974; Rousseau et al. 1997) and one of only a few large $(>15 \mathrm{~cm})$ erect indigenous macroalgae in Limfjorden. S. muticum and H. siliquosa both have coarsely branched thalli that create a relatively large canopy which may be a suitable habitat for a wide variety of fauna and flora (Mukai 1971; Withers et al. 1975; Haage 1976; Norton and Benson 1983; Aguilar-Rosas and Galindo 1990; Taylor and Cole 1994). During the course of a year, however, the habit of S. muticum is characterised by dramatic variation whereas the habit of $H$. siliquosa is much more constant (Wernberg et al. 2001): in spring, $S$. muticum grows from a small $(10-15 \mathrm{~cm})$ perennial basal structure into a large $(100-120 \mathrm{~cm})$ erect canopy before it senesces back in autumn, whereas $H$. siliquosa retains an erect canopy of intermediate size $(\sim 35 \mathrm{~cm})$ throughout the year. We proposed that these quantitative (host size) and qualitative (host phenology) differences in resource (canopy habitat) availability were important to the epibiota community, and therefore tested the hypothesis that $S$. muticum and $H$. siliquosa support different epibiota biomass and species composition.

\section{Methods}

\section{Study site}

The study was conducted in Dråby Vig $\left(56^{\circ} 49^{\prime} 92^{\prime \prime} \mathrm{N} 08^{\circ} 50^{\prime} 70^{\prime \prime} \mathrm{E}\right)$, western Limfjorden (Denmark). The study site was located on an eastern shore protected from the predominantly westerly winds. The surface temperature and salinity range annually from -1 to $25^{\circ} \mathrm{C}$ and 25 to $28 \%$, respectively (Groos et al. 1996). S. muticum has been present at the study site since the late 1980's (WernbergMøller et al. 1998a) and now forms dense beds from 2 to $4 \mathrm{~m}$ depth (Wernberg-Møller et al. 1998b). H. siliquosa is present as scattered individuals among the S. muticum (Wernberg-Møller et al. 1998b). All samples were taken from within the main Sargassum bed.

\section{Sampling}

Epibiota were sampled once a month from May 1997 to January 1998, except October and December. Scuba divers haphazardly collected four to six individuals of each of $S$. muticum and $H$. siliquosa by carefully, but swiftly, placing a $1 \mathrm{~mm}$ mesh bag over the thallus of each alga (Norton and Benson 1983; Connolly 1995). The thallus was then detached from the substratum and brought ashore to be preserved in $70 \%$ ethanol.

In the laboratory, individually collected thalli were placed in white plastic trays and cleaned for epibiota by gentle flushing and brushing. Water from the trays was filtered through a $1 \mathrm{~mm}$ sieve to retain the epibiota. Fresh weight $(\mathrm{FW})$ of the preserved $S$. muticum and $H$. siliquosa was measured after spinning the algal material in a mesh bag to remove excess water (Norton and Benson 1983). The epibiota was identified to lowest possible taxonomical level (usually species or genus). Faunal and algal taxonomy follow Hayward and Ryland (1996) and Nielsen et al. (1995), respectively. Individuals were counted for all taxa except colonial taxa (e.g. Obelia spp.) and taxa otherwise without distinct individuals (e.g. filamentous algae). These taxa were registered as one individual. The wet weight (WW) of the preserved epibiota was determined after blotting with paper towels. For taxa with large individuals (e.g. Styela clava), WW was determined for each sample; whereas in taxa with small individuals (e.g. Phtisica marina), WW was estimated from mean values per individual obtained from measurements of large batches. Taxa with extremely small (often $<1 \mathrm{~mm}$ ) and inconspicuous individuals (e.g. Nematoda spp.) were registered as having a biomass of $0.001 \mathrm{~g} \mathrm{WW}$ regardless of abundance. To alleviate the large differences in skeletal and shell components among taxa, epibiota WW was converted to ash free dry weight (AFDW) by applying conversion factors from Lappalainen and Kangas (1975), Ricciardi and Bourget (1998) and our own unpublished data.

\section{Data analysis}

A total of 70 samples, 35 from each species of macroalga, covering seven sampling times, were examined. Algal FW was used as a proxy for canopy habitat. This was justified by tight correlations between algal height and biomass (Wernberg et al. 2001) as well as height and canopy volume (sensu Hacker and Steneck 1990) for both macroalgal species (T. Wernberg, M.S. Thomsen and P.A. Staehr, unpublished data). Because of the relative importance of epibiota taxa with a few large or an obscure definition of individuals, biomass (mg AFDW/100 $\mathrm{g} \mathrm{FW}$ alga) was the preferred unit for analysis and presentation, although primary data are also presented in other units commonly encountered in the literature (see Fig. 1).

First, using a mixed-model two-way ANOVA, we tested whether the canopy habitat offered by the collected specimens of $S$. muticum and $H$. siliquosa conformed to the general pattern hypothesised to influence epibiota $\left(\mathrm{H}_{0}: S\right.$. muticum and $H$. siliquosa offer equal amounts of canopy habitat, and there are no temporal differences in the amount of canopy habitat offered by either of these species). Then, using a mixed-model two-way ANCOVA, we tested whether $S$. muticum and $H$. siliquosa had different amounts of associated epibiota $\left(\mathrm{H}_{0}: S\right.$. muticum and $H$. siliquosa have equal amounts of associated epibiota at all sampling times when adjusting for differences in canopy habitat). In both analyses, algal species ('Species') was considered a fixed factor and sampling time ('Time') a random factor. Canopy habitat (thallus size, g FW) was the covariate. These analyses were performed on a slightly modified data set where, to balance the design, the mean of the four samples was added to each of the May data sets, and one sample was randomly removed from each of $S$. muticum/November and $H$. siliquosa/July data sets (see Table 2). Prior to analysis, data were $\log$ transformed to meet parametric assumptions of normality $\left(\chi^{2}\right.$ test, $P<0.05)$ and homoscedasticity (Cochran's C-test, $P<0.05$ ).

To test if there were temporal differences and if epibiota communities were different between $S$. muticum and $H$. siliquosa, a two-way crossed ANOSIM was performed in PRIMER (Clarke and Gorley 2001) $\left(\mathrm{H}_{0}\right.$ : there are no temporal differences and there are no differences in the epibiota communities of $S$. muticum and $H$. siliquosa). Bray-Curtis similarity matrices were constructed from both square root-transformed biomass data and presence/absence (p/a)-transformed data. The first transformation was chosen to reduce the influence of large variability among replicates, while retaining the quantitative information on the dominance of abundant taxa (Clarke and Warwick 1996), whereas the latter transformation was chosen to emphasise effects purely due to species distributions. The similarity data were plotted in nMDS plots. We used principal axis correlation (Belbin 1995) to correlate individual taxa to the pattern produced by the nMDS. This procedure yields a principal axis correlation coefficient (PCC) for each taxon, which can be interpreted as the weight of that taxon in driving the observed patterns (Belbin 1995). 
Fig. 1A-F Seasonal development in epibiota loading on Sargassum muticum and $\mathrm{Ha}$ lidrys siliquosa given as species (taxa), abundance and biomass per individual $(\mathbf{A}, \mathbf{C}, \mathbf{E})$ and per biomass of alga $(\mathbf{B}, \mathbf{D}, \mathbf{F})$. Error bars are standard errors ( $n$ values can be found in Table 2)

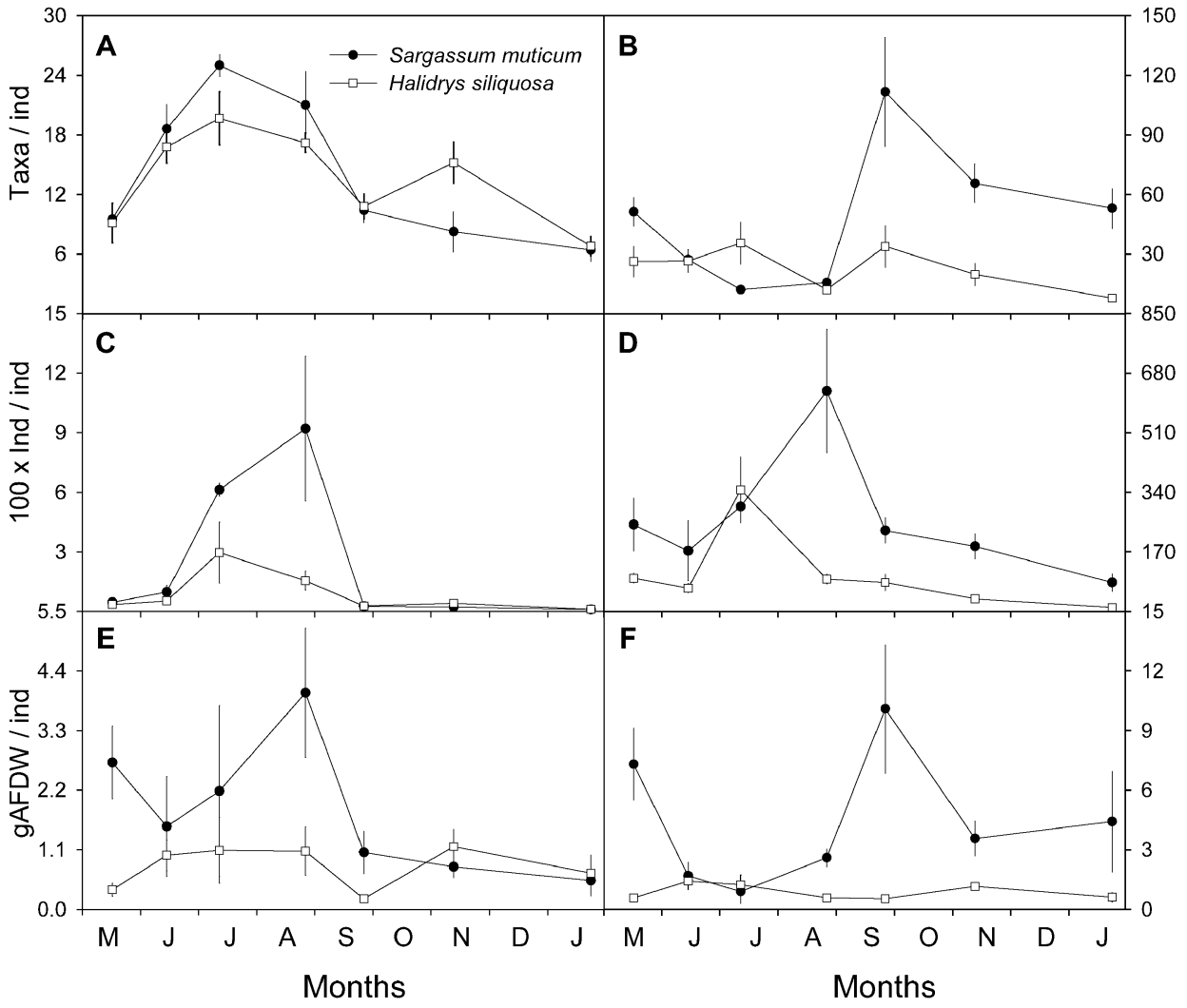

\section{Results}

Overall, there were no statistically significant differences in the biomass of the sampled S. muticum and H. siliquosa thalli (Table 1). The effect of sampling time and the interaction between host species and sampling time was, however, highly significant. There was also a highly significant difference in thallus biomass among species at different sampling times. These results agree closely with the observations of Wernberg et al. (2001), and suggest that the canopy habitat of the sampled specimens conformed to the quantitative and qualitative patterns hypothesised to influence the epibiota communities.

A total of 53 epibiota taxa, representing nine animal phyla (46 taxa) and three algal divisions (seven taxa), were found on the 70 individuals of $S$. muticum and $H$. siliquosa sampled (Table 2). With the exception of 'Malacostraca (other)', a quantitatively insignificant group that was found only on S. muticum, all taxa were found on both species of macroalgae. Arthropoda (Crustacea) was the most abundant phylum in terms of number of taxa, and Chordata (Urochordata) in terms of biomass.

The absolute species richness of epibiota per individual (Fig. 1A) followed the same temporal pattern on both macroalgae, with an increasing number of associated taxa from spring towards a summer peak in July. There was a tendency for S. muticum to have more species early in the year and $H$. siliquosa late in the year. The relative species richness per biomass (Fig. 1B) showed a markedly different pattern, where $S$. muticum had a distinct peak in
Table 1 Test of differences in canopy habitat availability. ANOVA on LOG-transformed biomass (g FW) of collected Sargassum muticum and Halidrys siliquosa individuals

\begin{tabular}{lrlcc}
\hline Effect & $d f$ & MS & $F$ & $P$ \\
\hline Species & 1 & 1.0515 & 1.75 & 0.23 \\
Time & 6 & 0.8903 & 15.4 & $<0.001$ \\
Species×Time & 6 & 0.6013 & 10.4 & $<0.001$ \\
Residual & 56 & 0.0580 & & \\
Cochran's $C$ & & $C=0.22$ & & \\
\hline
\end{tabular}

September and retained higher relative species numbers late in the year, while $H$. siliquosa did not appear to have any systematic temporal variation. The epibiota on both macroalgae showed a distinct summer peak in absolute (Fig. 1C) and relative (Fig. 1D) abundance. There was, however, a time lag between maximum abundance on $H$. siliquosa (July) and S. muticum (August). Biomass of epibiota (Fig. 1E, F) had a peak in early and late summer for $S$. muticum but was constant for $H$. siliquosa. $H$. siliquosa generally supported lower epibiota biomass than S. muticum.

The ANCOVA revealed homogeneity of slopes in regressions between algal size (g FW) and epibiota load ( $g$ WW/100 g FW alga) both between host species $(P=0.66)$ and among sampling times $(P=0.99)$, i.e. irrespective of host species and sampling time, the ratio of algal size to epibiota load remained the same. Correlation analysis on pooled data showed this common relationship between thallus size and epibiota load to be weakly negative but 


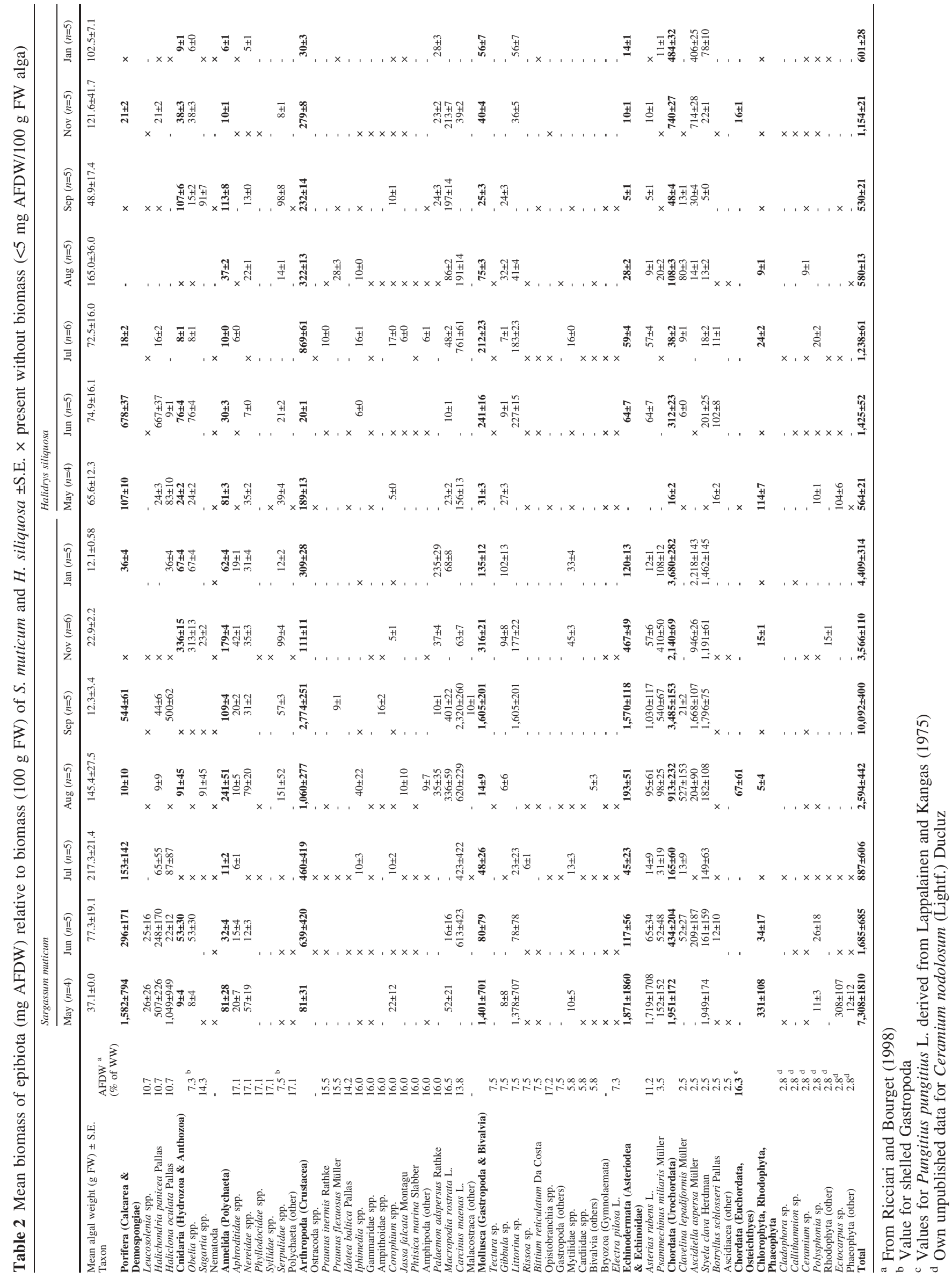


Table 3 Test of differences in epibiota biomass. ANCOVA for the effect of (host) species and (sampling) time on the relative epibiota load (biomass). Means adjusted for covariance with thallus size (g FW). Both epibiota biomass and thallus size were log transformed prior to analysis. $d f$ adjusted for the addition of two pseudo-samples in May

\begin{tabular}{lrlll}
\hline Effect & $d f$ & MS & $F$ & $P$ \\
\hline Species & 1 & 3.773591 & 5.993625 & 0.0499 \\
Time & 6 & 0.323532 & 2.008443 & 0.0808 \\
Species $\times$ time & 6 & 0.629601 & 3.908470 & 0.0026 \\
Residual & 53 & 0.161086 & & \\
Cochran's $C$ & & \multicolumn{2}{l}{$C_{\text {epibiota load }}=0.31, C_{\text {thallus size }}=0.22$} \\
\hline
\end{tabular}

highly significant (Pearson Product Moment Correlation; $r=-0.32, P=0.006, n=70)$. Analyses on the means adjusted for differences in thallus size (Table 3) showed that the two macroalgae supported significantly different epibiota biomasses. There was no statistically significant effect of sampling time on epibiota biomass, suggesting a temporally constant epibiota load on both macroalgae when adjusted for temporal variation in thallus size. This result, however, must be interpreted cautiously as the $P$ value is relatively low. The interaction between species and sampling time was highly significant, showing that time of year exaggerated differences in epibiota loading between the two host species.

A three-dimensional ordination of community data (Fig. 2A-D) was necessary to obtain satisfactory stress values. Only dimension 2 versus dimension 3 is presented here, as this was the most informative plot in terms of apparent groupings. With both the p/a and the square roottransformed data, the ordination separated the samples into broad groups corresponding to samples from the two host species (Fig. 2A, C) and the different sampling times (Fig. 2B, D). These groupings were highly significant (Table 4). Global $R$ values revealed that the species-wise groupings were generally weaker than the time-wise groupings, and that this pattern was most pronounced for the p/a-transformed data. This suggests that host species was important to epibiota biomass, whereas sampling time was important to epibiota community composition. The strong influence of sampling time on epibiota community structure can be seen in Fig. 2D as a clear unidirectional counter-clockwise succession of pair-wise monthly samples.

It was primarily the epibiota taxa with large, abundant individuals (Table 1), such as tunicates and crabs, that were responsible for the pattern (Table 5) seen in Fig. 2A, B whereas the patterns seen in Fig. 2C, D were mainly driven by the taxa with smaller, less abundant individuals. The differences in what taxa were driving these two ordinations suggest that differences between host species (more predominant with the square root-transformed data) are caused by differences in epibiota biomass of a constant subset of taxa rather than by differences in the kinds of associated taxa. The importance of small, infrequent taxa to the seasonal pattern (strongly dominant from the p/a-transformed data) suggests that the differences among
Fig. 2A-D nMDS plots of dimension 3 versus dimension 2 for all samples collected, and monthly averages for each algal species. A, B square root-transformed data (stress $=0.20$ ). $\mathbf{C}, \mathbf{D}$ presence/absence-transformed data (stress=0.19). $S S . m u$ ticum, $H$ H. siliquosa

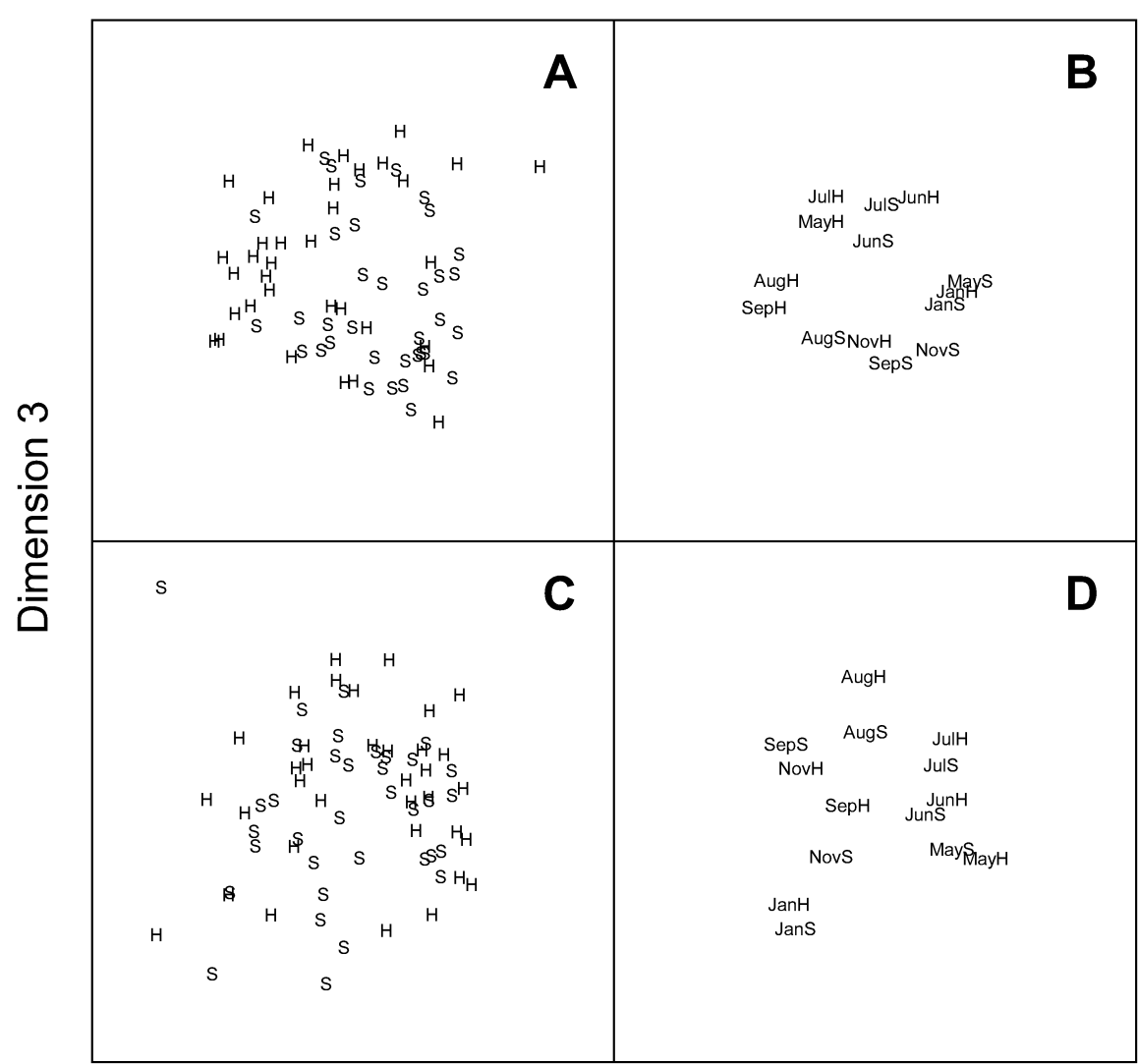


Table 4 Results of two-way crossed ANOSIM for the effect of (host) species and (sampling) time on epibiota loading. $P<0.001$ for all $R$. A square root-transformed data, $B$ p/a-transformed data

\begin{tabular}{lll}
\hline & & Global $R$ \\
\hline Species & A & 0.338 \\
Time & B & 0.283 \\
& A & 0.492 \\
& B & 0.581 \\
\hline
\end{tabular}

(sampling) times are caused by differences in community structure (i.e. species present) rather than by differences in epibiota biomass. In other words, the main difference between $S$. muticum and $H$. siliquous is the abundance of epibiota, whereas the total epibiota community exhibits a clear parallel seasonal succession on both algae.

\section{Discussion}

Our results show that the invasive $S$. muticum and the indigenous $H$. siliquosa support different amounts of epibiota, and that time of year exaggerates these differences. Further, our results suggest that the quantitative differences in epibiota load between $S$. muticum and $H$. siliquosa are matched only by relatively weak differences in epibiota community structure. Epibiota community structure on both host species showed a clear, almost parallel, temporal development.

Habitat architecture or complexity is important to epibiota, particularly to small crustaceans (Hacker and Steneck 1990; Duffy and Hay 1991; Hacker and Madin 1991; Taylor and Cole 1994). Jephson and Gray (1977) noted that $H$. siliquosa generally has few epibiota species compared to $S$. muticum. Although they have the same basic morphology (Jensen 1974), the thallus of H. siliquosa clearly has fewer and coarser branches than the annual thallus of S. muticum. Both Hacker and Steneck (1990) and Taylor and Cole (1994) found epifaunal densities to be significantly higher on algae with more complex thalli, suggesting that a similar mechanism could explain the quantitative differences between $S$. muticum and $H$. siliquosa in Limfjorden.

We found a negative correlation between thallus size and the relative amount of epibiota biomass supported.
This may seem counter-intuitive, but could be interpreted as an 'escape by growth' mechanism where the algae avoid detrimental grazing by satiating herbivores (Lobban and Harrison 1994). This is unlikely, however, as the ANCOVA showed no differences in slopes between the seasonally variable $S$. muticum and the seasonally constant (i.e. no 'escape growth') H. siliquosa. We consider it more likely that this negative correlation is an artefact of epibiota behaviour, rather than an algal growth strategy, as the primary site of attachment for some of the abundant (by biomass) sessile animals (e.g. Styela clava) was clearly around the main axis and holdfast on both host species, as it has also been observed on other macroalgae (Arrontes 1990). As the size of these parts of the thallus is relatively constant across a range of algal sizes and seasons (Wernberg-Møller et al. 1998b), the amount of epibiota which can be supported by them is independent of algal size. Smaller thalli will thus have a higher relative epibiota load than larger thalli. In S. muticum, this intraindividual epibiota distribution may be due to, or enhanced by, high levels of phenolic compounds produced by the rapidly growing thallus (Gorham and Lewey 1984). Jephson and Gray (1977) made similar speculations after observing extreme fouling of $S$. muticum around the time of senescence, when the concentration of these compounds drops (Gorham and Lewey 1984), something we also observed in Limfjorden around August/September. In contrast, Norton and Benson (1983) generally found more epifauna (mainly amphipods and gastropods) on the distal parts of the $S$. muticum thallus. $H$. siliquosa has been observed to slough off epidermal cells, a mechanism thought to control its epiphytes (Moss 1982).

Habitat quality (i.e. temporal stability) did not appear to be an important factor for epibiota community structure in Limfjorden, as S. muticum (highly variable habit) and $H$. siliquosa (constant habit) had almost identical species associated with them. Similar results were obtained by Viejo (1999) in northern Spain and Jephson and Gray (1977) in southern England. In New Zealand, Taylor and Cole (1994) studied ten different brown algae and found that most had distinct epifaunal assemblages, while individual epifaunal taxa showed little host specificity and were found on several host species. This general pattern of a lack of host specificity may be an epibiota adaptation to the fluctuating environment of temperate regions: host
Table 5 Principal axis correlation coefficients (PCC) for the 10 taxa best correlated to (i.e. most determinant for) the threedimensional nMDS ordinations. $C$ Chordata (Urochordata), $A$ Arthropoda (Crustacea), $M$ Mollusca, An Annelida (Polychaeta), $E$ Echinodermata (Echinoidae), $\mathrm{Cn}$ Cnidaria, $\mathrm{Ch}$ Chlorophyta

\begin{tabular}{|c|c|c|c|}
\hline \multicolumn{2}{|l|}{ Square root-transformed data } & \multicolumn{2}{|l|}{ P/a-transformed data } \\
\hline Taxon & PCC & Taxon & $\mathrm{PCC}$ \\
\hline Ascidiella adspersa (C) & 0.80 & Rissoa spp. (M) & 0.74 \\
\hline Styela clava $(\mathrm{C})$ & 0.70 & Polychaeta (other) (An) & 0.74 \\
\hline Macropodia rostrata (A) & 0.61 & Obelia spp. (Cn) & 0.73 \\
\hline Carcinus maenas (A) & 0.61 & Clavelina lepadiformis (C) & 0.69 \\
\hline Rissoa spp. (M) & 0.60 & Mytilidae spp. (M) & 0.69 \\
\hline Praunus inermis (A) & 0.55 & Iphimedia spp. (A) & 0.68 \\
\hline Phtisica marina (A) & 0.52 & Phtisica marina (A) & 0.66 \\
\hline Littorina spp. (M) & 0.52 & Ceramium sp. (Ch) & 0.65 \\
\hline Serpulidae spp. (An) & 0.51 & Praunus inermis (A) & 0.63 \\
\hline Psammechinus miliaris (E) & 0.48 & Nematoda spp. & 0.63 \\
\hline
\end{tabular}


phenology may not matter to many epibiota species because they follow the same seasonality as the algae. This is perhaps accentuated by the clear temporal change in epibiota observed in this and many other studies from temperate regions (Mukai 1971; Withers et al. 1975; Jephson and Gray 1977; Arrontes 1990; Kendrick and Burt 1997).

Crustacea comprised almost $30 \%$ of all epifaunal taxa found in this study. Norton and Benson (1983) and Pavia et al. (1999) found that this group of epifauna (mainly amphipods) were highly mobile and actively selected favourable host macroalgae. Gunnill (1982), however, found that no amphipods were able to colonize the intertidal fucoid Pelvetia fastigiata (J. Agardh) De Toni over a $30 \mathrm{~m}$ distance, indicating that the range over which this selective mobility occurs is limited. Dispersal barriers may be a real problem in the establishment and development of an H. siliquosa epibiota community in Limfjorden because the individual plants are scattered several metres apart among the $S$. muticum individuals (Wernberg-Møller et al. 1998b).

Using a similar approach to us, Viejo (1999) estimated the impact of $S$. muticum invasion on mobile epifauna by comparing contemporary patterns of abundance and species distributions among S. muticum and indigenous equivalents (Cystoseira nodicaulis and Fucus vesiculosus). As she found no major differences in mobile epibiota associated with any of these algae, she concluded that local epibiota colonised $S$. muticum equally well as they colonised either of the indigenous host species, and thus that there was no effect of its invasion. Since no preinvasion data were available, such an argument assumes that the total epibiota community had not already been changed, and this in turn probably depends on a combination of the relative abundance of the invader and the time it had been present or dominant in the system. This seriously reduces the power of any conclusion derived from a retained null hypothesis (i.e. no differences among invader and indigenous species). S. muticum has been a dominant component of the macroalgal flora at our study site for more than 10 years (Wernberg-Møller et al. 1998a), and because of large differences in abundance of the two macroalgae (Wernberg et al. 2001) it cannot be ruled out that the epibiota community structure radically changed with the invasion of $S$. muticum and that the contemporary epibiota community structure of $H$. siliqu$o s a$ is, to a large degree, the result of a 'spill-over' effect. The observed quantitative differences in epibiota between $S$. muticum and $H$. siliquosa are, however, independent of this, and thus a real consequence of the introduction of $S$. muticum.

Based on the findings of this study, we find it unlikely that the introduction of $S$. muticum to Limfjorden has caused any major changes in local macroalgal epibiota community structure. It does, however, appear that the system now supports a much higher standing stock of epibiota than was previously the case. This appears to be a general pattern in the systems invaded by $S$. muticum, as similar conclusions were reached by Wither et al. (1975) in southern England and by Viejo (1999) in northern Spain. The consequences of these quantitative changes are unknown at the system level, but they could include altered food webs because of increased availability of food items or increased grazing on algal propagules and recruits, perhaps reinforcing the position of $S$. muticum as a dominant due to the regenerative abilities of the genus (Kendrick and Walker 1994).

Acknowledgements We wish to thank M. Lauersen, County of Ringkøbing, for early talks on S. muticum in Limfjorden. We are grateful to M.A. Vanderklift, University of Western Australia, for valuable comments on various stages of this manuscript. This work complies with the laws and regulations of Roskilde University and Denmark

\section{References}

Aguilar-Rosas R, Galindo AM (1990) Ecological aspects of Sargassum muticum (Fucales, Phaeophyta) in Baja California, Mexico: reproductive phenology and epiphytes. Hydrobiologia 204/205:185-190

Ambrose RF, Nelson BV (1982) Inhibition of giant kelp recruitment by an introduced brown alga. Bot Mar 25:265-267

Arrontes J (1990) Composition distribution on host and seasonality of epiphytes on three intertidal algae. Bot Mar 33:205-212

Belbin L (1995) PATN pattern analysis package technical reference. CSIRO, Division of Wildlife and Ecology, Australia

Christensen T (1984) Sargassotang, en ny algeslaegt i Danmark (in Danish). URT 4:99-104

Clarke KR, Gorley RN (2001) Primer v5: user manual/tutorial. PRIMER-E Ltd, Plymouth, UK

Clarke KR, Warwick RM (1996) Change in marine communitiesan approach to statistical analysis and interpretation. Plymouth Marine Laboratory, Plymouth, UK

Connolly RM (1995) Effects of removal of seagrass canopy on assemblages of small, motile invertebrates. Mar Ecol Prog Ser 118:129-137

Cosson J (1999) On the progressive disappearance of Laminaria digitata on the coasts of Calvados (in French). Cryptogam Algol 20:35-42

Critchley AT, Nienhuis PH, Verschuure K (1987) Presence and development of populations of the introduced brown alga Sargassum muticum in the southwest Netherlands. Hydrobiologia 151/152:245-255

Den Hartog C (1997) Is Sargassum muticum a threat to eelgrass beds? Aquat Bot 58:37-41

Duffy JE, Hay ME (1991) Food and shelter as determinants of food choice by a herbivorous marine amphipod. Ecology 72:12861298

Fernandez C (1999) Ecology of Sargassum muticum (Phaeophyta) on the north coast of Spain: IV. Sequence of colonization on a shore. Bot Mar 42:553-562

Fletcher RL, Fletcher SM (1975) Studies on the recently introduced brown alga Sargassum muticum (Yendo) Fensholt. I. Ecology and reproduction. Bot Mar 18:149-156

Gorham J, Lewey SA (1984) Seasonal changes in the chemical composition of Sargassum muticum. Mar Biol 80:103-107

Groos JM, Lauersen M, Deding J, Jensen B, Larsen F, Platz E-M, Bendtsen A, Rasmussen G (1996) Vandmiljø i Limfjorden 1995 (in Danish). Limfjordsovervågningen, Ringkøbing Amtskommune, Viborg Amt og Nordjyllands Amt

Gunnill FC (1982) Macroalgae as habitat patch islands for Scutellum lamellipes (Copepoda: Harpacticoida) and Ampithoe tea (Amphipoda: Gammaridae). Mar Biol 69:103-116

Haage P (1976) Studies on the Baltic Fucus macrofauna. Department of Zoology and Askö Laboratory, University of Stockholm, Sweden 
Hacker SD, Madin LP (1991) Why habitat architecture and color are important to shrimps living in pelagic Sargassum: use of camouflage and plant-part mimicry. Mar Ecol Prog Ser 70:143155

Hacker SD, Steneck RS (1990) Habitat architecture and the abundance and body-size-dependent habitat selection of a phytal amphipod. Ecology 71:2269-2285

Hayward PJ, Ryland JS (1996) Handbook of the marine fauna of north-west Europe. Oxford University Press, Oxford, UK

Jensen JB (1974) Morphological studies in Cystoseiraceae and Sargassaceae (Phaeophyceae) with special reference to apical organization. Univ Calif Publ Bot 68:1-61+16 plates

Jephson NA, Gray PWG (1977) Aspects of the ecology of Sargassum muticum (Yendo) Fensholt, in the Solent region of the British Isles. I. The growth cycle and epiphytes. In: Keegan BF, Ceidigh PO, Boaden PJS (eds) Biology of benthic organisms. Proceedings 11th EMBS. Pergamon Press, Oxford, UK, pp 367-375

Karlsson J, Loo LO (1999) On the distribution and the continuous expansion of the Japanese seaweed Sargassum muticum in Sweden. Bot Mar 42:285-294

Kendrick GA, Burt JS (1997) Seasonal changes in epiphytic macroalgae assemblages between offshore exposed and inshore protected Posidonia sinuosa Cambridge et Kuo seagrass meadows, Western Australia. Bot Mar 40:77-85

Kendrick GA, Walker DI (1994) Role of recruitment in structuring beds of the Sargassum spp. (Phaeophyta) at Rottnest Island, Western Australia. J Phycol 30:200-208

Knoepffler-Peguy M, Belsher T, Boudouresque CF, Lauret M (1985) Sargassum muticum begins to invade the Mediterranean. Aquat Bot 23:291-296

Lappalainen A, Kangas P (1975) Littoral benthos of the northen baltic sea II. Interrelationships of wet, dry and ash-free dry weights of macrofauna in the Tvärminne area. Int Revue Ges Hydrobiol 60:297-312

Lobban CS, Harrison PJ (1994) Seaweed ecology and physiology. Cambridge University Press, Cambridge, UK

Moss B (1982) The control of epiphytes by Halidrys siliquosa (L.) Lyngb. (Phaeophyta, Cystoseiraceae). Phycologia 21:185-188

Mukai H (1971) The phytal animals on the thalli of Sargassum serratifolium in the Sargassum region, with reference to their seasonal fluctuations. Mar Biol 8:170-182

Nielsen R, Kristiansen A, Mathiesen L, Mathiesen H (1995) Distributional index of the benthic macroalgae of the Baltic Sea area. Acta Bot Fenn 155:1-51

Norton TA, Benson MR (1983) Ecological interactions between the brown seaweed Sargassum muticum and its associated fauna. Mar Biol 75:169-177
Núnez-López RA, Casas Valdez M (1998) Seasonal variation of seaweed biomass in San Ignacio Lagoon, Baja California Sur, Mexico. Bot Mar 41:421-426

Pavia H, Carr H, Aberg P (1999) Habitat and feeding preferences of crustacean mesoherbivores inhabiting the brown seaweed Ascophyllum nodosum (L.) Le Jol. and its epiphytic macroalgae. J Exp Mar Biol Ecol 236:15-32

Ricciardi A, Bourget E (1998) Weight-to-weight conversion factors for marine benthic macroinvertebrates. Mar Ecol Prog Ser $163: 245-251$

Rousseau F, Leclerc MC, De Reviers B (1997) Molecular phylogeny of European Fucales (Phaeophyceae) based on partial large-subunit rDNA sequence comparisons. Phycologia 36: 438-446

Rueness J (1989) Sargassum muticum and other introduced Japanese macroalgae: biological pollution of European coasts. Mar Pollut Bull 20:173-176

Staehr PA, Pedersen MF, Thomsen MS, Wernberg T, KrauseJensen D (2000) Invasion of Sargassum muticum in Limfjorden (Denmark) and its possible impact on the indigenous macroalgal community. Mar Ecol Prog Ser 207:79-88

Taylor RB, Cole RG (1994) Mobile epifauna on subtidal brown seaweeds in northeastern New Zealand. Mar Ecol Prog Ser 115:271-282

Thelin I (1989) The Japweed Sargassum muticum has arrived in Norway: what consequences can be expected? (in Norwegian). Blyttia 47:29-34

Viejo RM (1997) The effects of colonization by Sargassum muticum on tidepool macroalgal assemblages. J Mar Biolog Assoc UK 77:325-340

Viejo RM (1999) Mobile epifauna inhabiting the invasive Sargassum muticum and two local seaweeds in northern Spain. Aquat Bot 64:131-149

Wernberg T, Thomsen MS, Staehr PA, Pedersen MF (2001) Comparative phenology of Sargassum muticum and Halidrys siliquosa (Phaeophyceae, Fucales) in Limfjorden (Denmark). Bot Mar 44:31-39

Wernberg-Møller T, Thomsen MS, Staehr PA (1998a) Invasion of japweed in Denmark-status anno 1998 (in Danish). URT 22:128-132

Wernberg-Møller T, Thomsen MS, Staehr PA (1998b) Studies on the ecology of Sargassum muticum (Yendo) Fensholt in Limfjorden. MSc thesis, Department of Life Sciences and Chemistry, Roskilde University, Denmark

Withers RG, Farnham WF, Lewey S, Jephson NA, Haythorn JM, Gray PWG (1975) The epibionts of Sargassum muticum in British waters. Mar Biol 31:79-86 